\title{
Uji Efek Aplikasi Takaran Biochar dan Kompos Kirinyuh Tahun Ke Dua terhadap Pertumbuhan dan Hasil Selada Darat (Lactuca Sativa L.)
}

\author{
Eduardus Yosef Neonbeni ${ }^{\mathrm{a}}$, Veronika Boe ${ }^{\mathrm{b}}$, Arnoldus Klau Berek ${ }^{\mathrm{c}}$ \\ ${ }^{a}$ Fakultas Pertanian, Universitas Timor, Kefamenanu, TTU-NTT, Indonesia, email: ambeni02@yahoo.com \\ ${ }^{b}$ Fakultas Pertanian, Universitas Timor, Kefamenanu, TTU - NTT, Indonesia, email: veronikaboe7@gmail.com \\ ${ }^{c}$ Fakultas Pertanian, Universitas Timor, Kefamenanu, TTU-NTT, Indonesia, email: b3r3kkl4u@gmail.com
}

\section{Article Info}

Article history:

Received 22 Januari 2019

Received in revised form 26 Mei 2019

Accepted 14 Juni 2019

DOI:

https://doi.org/10.32938/sc.v4i02.632

\section{Keywords:}

Takaran biochar

Kompos Kirinyuh

Lactuca sativa $\mathrm{L}$.

\section{Abstrak}

Selada darat (Lactucasativa L) merupakan salah satu komoditi sayuran hortikultura yang memiliki prospek dan nilai komersial yang tinggi. Penelitian ini bertujuan menguji efek aplikasi takaran biochar dan kompos kirinyuh tahun kedua terhadap sifat fisik tanah, pertumbuhan dan hasil tanaman selada darat. Penelitian dilaksanakan pada bulan Maret - Mei 2018, dikebun percobaan Fakultas Pertanian Universitas Timor. Rancangan yang digunakan dalam penelitian adalah rancangan acak lengkap faktorial 5 x 3 yang di ulang 3 kali. Faktor pertama adalah takaran biochar yang terdiri dari 5 aras, yaitu 0 t/ha, 2,5 t/ha, 5 t/ha, 7,5 t/ha dan 10 t/ha. Faktor kedua adalah kompos kirinyuh yang terdiri dari 3 aras yaitu tanpa kompos kirinyuh $0 \mathrm{t} / \mathrm{ha}, 5 \mathrm{t} / \mathrm{ha}$ dan $10 \mathrm{t} / \mathrm{ha}$. Campuran tanah, biochar dan kompos kirinyuh yang digunakan tahun sebelumnya dikering anginkan, dihaluskan, diayak dan dimasukan kembali ke dalam pot, diairi dan ditanami dengan bibit selada yang telah disemaikan 2 minggu sebelumnya. Parameter yang diamati dalam penelitian ini adalah Suhu tanah, Kadar lengas tanah, Daya hantar listrik, $\mathrm{pH}$ tanah, Berat volume tanah, Tinggi tanaman, Jumlah daun, Luas daun, Berat segar trubus per tanaman, Berat kering per tanaman, Panjang akar, Berat segar akar, Berat kering akar, Rasio akar tajuk dan Indeks panen. Hasil penelitian menunjukkan bahwa perlakuan biochar pada takaran 2,5 t/ha menghasilkan trubus segar terberat 16,64 g/tanaman lebih tinggi dibandingkan tahun pertama ( $0 \mathrm{t} / \mathrm{ha}$ ) sedangkan kompos kirinyuh pada takaran $10 \mathrm{t} / \mathrm{ha}$ menghasilkan trubus segar seberat 15,11 $\mathrm{g} /$ tanaman lebih tinggi dari pada hasil tahun pertama $(0 \mathrm{t} / \mathrm{ha})$. Hasil tersebut menunjukkan adanya aging effect aplikasi biochar sekam padi dan kompos kirinyuh terhadap pertumbuhan dan hasil selada darat.

\section{Pendahuluan}

Selada (Lactuca sativa, L) merupakan salah satu komoditi sayuran hortikultura yang memiliki prospek dan nilai komersial yang cukup tinggi. Upaya pemenuhan kebutuhan tersebut perlu didukung dengan teknik budidaya selada darat secara kontinu dengan teknologi yang mampu memperbaiki dan mempertahankan kesuburan tanah. Kesuburan tanah sangat berkaitan erat dengan ketersediaan unsur hara yang dapat diserap oleh tanaman. Budidaya tanaman selada darat membutuhkan tanah yang subur. Sementara dilahan kering umumnya memiliki tanah yang tidak subur. Oleh karena itu,aplikasi kompos dan biochar sangat tepat untuk meningkatkan kesuburan tanah dan kemampuan tanah menyimpan unsur hara. Biochar dapat mengikat dan menyimpan unsur hara dan air untuk jangka waktu yang lebih lama. Biochar dan bahan-bahan hasil perubahannya atau biochar-derived organic materials (BDOMs) yang teroksidasi permukaan dapat berinteraksi dengan mineral tanah, nutrisi, dan kontaminan yang mengakibatkan peningkatan bahan organik yang distabilkan, retensi kation, ketersediaan hayati anion, dan penyerapan zat pereda organik yang berkurang (Mia dkk., 2016). Biochar merupakan arang hayati yang diperoleh dari pembakaran tidak sempurna sehingga menyisakan unsur hara dan $50 \%$ karbon (C) yang dapat meningkatkan kesuburan tanah (Gani, 2010). Penuaan biochar mengubah sifat fisik kimia, yang ada berbagai bahan organik yang berasal dari biochar (BDOM) dapat dibentuk. Perubahan ini memiliki konsekuensi signifikan untuk ketersediaan hayati dan transportasi nutrisi yang ada. Dalam hal ini, penuaan biochar, berfokus pada perubahan struktur, sifat kimia permukaan, dan interaksi biochar dan BDOM dengan nutrisi dan yang ada di dalam tanah (Mia dkk., 2016). Bila digunakan sebagai pembenah tanah bersama pupuk organik dan biochar dapat meningkatkan produktivitas serta retasi dan ketersediaan hara bagi tanaman (Gani, 2009).

Kompos merupakan sisa-sisa makhluk hidup yang telah mengalami pelapukan, bentuknya seperti tanah dan tidak berbau. Misalnya daun-daunan, ranting kayu, cacahan rumput, limbah sayur, limbah buah-buahan dan kotoran ternak. Manfaat kompos yang utama pada tanah yaitu dapat mengembalikan kesuburan tanah, meningkatkan aktivitas mikroba tanah, meningkatkan ketersedian hara didalam tanah, tanah menjadi lebih gembur dan tanaman akan tumbuh lebih subur dan kualitas serta kuantitas hasil panennya lebih baik dari pada tanaman tanpa diberikan kompos. Kompos memiliki sifat-sifat yang beragam tergantung pada tingkat kematangan, komposisi bahan baku dan proses pengomposan pada saat pembuatan kompos (Anas dkk., 2003). Penggunaan biochar dan pupuk organik dalam budidaya tanaman selada darat pada tanah vertisol belum diketahui oleh masyarakat, baik di kabupaten TTU (Timor Tengah Utara) maupun di Belu dan Malaka. Beberapa hasil penelitian terdahulu sudah menggunakan biochar dan beberapa jenis pupuk organik namun belum mendapatkan hasil yang menunjukan dampak yang nyata terhadap pertumbuhan dan hasil selada darat. Hasil penelitian Subani (2016) menunjukkan bahwa efek teh kompos tidak nyata pada tanaman, terutama ketika teh kompos diberikan dengan kombinasi biochar. Penelitian Opat (2017) membuktikan bahwa pemberian biochar sekam padi pada tanah vertisol tidak berpengaruh nyata terhadap hasil selada darat (Lactuca sativa, L.) walaupun pemberian kompos kirinyuh 10 t/ha menghasilkan trubus segar lebih berat. Hal ini disebabkan oleh kurang matangnya pupuk organik yang diberikan sehingga saat diaplikasikan pada tanaman selada darat (Lactuca sativa, L.), proses dekomposisi masih terus terjadi sehingga berdampak pada pertumbuhan tanaman. Tingkat kematangan yang tepat akan menghindari terjadinya imobilisasi hara. Respon tanaman merupakan indikator utama dari kematangan kompos. Schuchard (1998) menyatakan bahwa indikator utama dari tingkat kematangan kompos adalah pertumbuhan tanaman yang dipengaruhi oleh pemberian kompos tersebut. Mikroba ini memberikan pengaruh yang baik terhadap kualitas pupuk organik, sedangkan ketersediaan unsur hara dalam pupuk sangat dipengaruhi oleh lamanya waktu pengomposan dan waktu yang digunakan untuk inkubasi sehingga dapat mempengaruhi pertumbuhan tanaman (Siburian, 2007).

Masa inkubasi sangat menentukan kematangan dari suatu kompos. Apabila masa inkubasi belum cukup, maka kompos yang dihasilkan kualitasnya kurang baik bila digunakan sebagai pupuk (Suwastika \& Utari, 2009). Keadaan ini diduga dengan penambahan waktu inkubasi dan takaran pupuk organik sudah cukup bagi mikroba untuk menguraikan bahan organik dan tambahan takaran pupuk untuk ketersediaan unsur hara bagi tanaman selada darat untuk menunjang pertumbuhan dan perkembangan tanaman selada darat. Semakin lama masa inkubasi menyebabkan ratio $\mathrm{C} / \mathrm{N}$ menjadi rendah, sehingga unsur hara cepat tersedia dan diserap oleh tanaman selada darat (Novizan, 2004). Hal ini sejalan dengan pendapat Yuniwati dkk. (2012), bahwa dengan lama waktu proses pengomposan, maka semakin banyak kesempatan bagi mikroorganisme untuk menguraikan bahan organik. Soetopo dkk (2010) yang menyatakan bahwa penggunaan kompos mampu berpengaruh positif terhadap pertumbuhan vegetatif dan generatif tanaman selada darat. Kompos dengan tingkat kematangan yang lebih baik memberikan hasil pertumbuhan yang lebih tinggi. Perbedaan tingkat kematangan kompos berpengaruh nyata terhadap tinggi tanaman, diameter batang, bobot tajuk basah dan bobot tajuk kering. Kriteria $\mathrm{C} / \mathrm{N}$ ratio dinyatakan secara tepat sehingga kompos yang diberikan ketanah tidak dapat menimbulkan proses bentuk nitrogen oleh mikroorganisme yang mengakibatkan ketersediaan nitrogen bagi tanaman yang berkurang unsur hara (Basuki, 1994). Penelitian ini dilakukan untuk menguji efektifitas bahan biochar dan kompos kirinyuh yang telah diaplikasikan pada penelitian sebelumnya terhadap tanaman salada darat (Opat, 2017). Hal ini untuk mengetahui seberapa besar pengaruh biochar dan kompos kirinyuh yang sudah diaplikasikan terhadap pertumbuhan selada darat pada penanaman di tahun kedua. Selain itu belum diketahui seberapa lama biochar dan kompos kirinyuh mampu menyedikan nuturisi yang cukup untuk pertumbuhan tanaman selada darat. Berdasarkan beberapa persoalan dan hasil penelitian di atas, maka perlu dilakukan penelitian lanjutan dengan judul uji efek aplikasi takaran biochar dan kompos kirinyuh pada tahun ke dua terhadap pertumbuhan dan hasil selada darat (Lactucal sativa L.).

\section{Metode}

Penelitian ini merupakan lanjutan dari penelitian yang telah dilaksanakan pada tahun 2017. Waktu yang dibutuhkan untuk menyelesaikan penelitian ini adalah dua bulan, Penelitian ini dimulai dari bulan Maret sampai bulan Mei 2018. Tempat penelitian ini dilakukan di kebun percobaan Fakultas Pertanian Universitas Timor, Kelurahan Sasi, Kecamatan Kota Kefamenanu, Kabupaten TTU.

Rancangan yang digunakan mengacu pada rancangan penelitian yang digunakan sebelumnya yaitu. Rancangan Acak Lengkap (RAL) faktorial 5 x 3 yang di ulang 3 kali. Faktor pertama adalah takaran biochar yang terdiri dari 5 aras, yaitu biochar $0 \mathrm{t} / \mathrm{ha}\left(\mathrm{B}_{0}\right)$, biochar $2,5 \mathrm{t} / \mathrm{ha}\left(\mathrm{B}_{1}\right)$, biochar $5 \mathrm{t} / \mathrm{ha}\left(\mathrm{B}_{2}\right)$, biochar $7,5 \mathrm{t} / \mathrm{ha}\left(\mathrm{B}_{3}\right)$, biochar $10 \mathrm{t} / \mathrm{ha}\left(\mathrm{B}_{4}\right)$. Faktor kedua adalah kompos kirinyuh yang terdiri dari 3 aras, yaitu kompos kirinyuh 0 t/ha (K0), kompos kirinyuh 5 t/ha $\left(\mathrm{K}_{1}\right)$, kompos kirinyuh $10 \mathrm{t} / \mathrm{ha}\left(\mathrm{K}_{2}\right)$. Sehingga terdapat 15 kombinasi perlakuan yaitu: $\mathrm{B}_{0} \mathrm{~K}_{0}, \mathrm{~B}_{0} \mathrm{~K}_{1}, \mathrm{~B}_{0} \mathrm{~K}_{2}, \mathrm{~B}_{1} \mathrm{~K}_{0}, \mathrm{~B}_{1} \mathrm{~K}_{1}, \mathrm{~B}_{1} \mathrm{~K}_{2}, \mathrm{~B}_{2} \mathrm{~K}_{0}, \mathrm{~B}_{2} \mathrm{~K}_{1}, \mathrm{~B}_{2} \mathrm{~K}_{2}, \mathrm{~B}_{3} \mathrm{~K}_{0}, \mathrm{~B}_{3} \mathrm{~K}_{1}$, $\mathrm{B}_{3} \mathrm{~K}_{2}, \mathrm{~B}_{4} \mathrm{~K}_{0}, \mathrm{~B}_{4} \mathrm{~K}_{1}, \mathrm{~B}_{4} \mathrm{~K}_{2}$ yang diulang sebanyak 3 kali sehingga terdapat 45 unit percobaan.Variabel yang diamati dalam penelitian ini adalah suhu tanah, $\mathrm{pH}$ tanah, daya hantar listrik tanah, kadar lengas tanah, berat volume tanah, tinggi 
tanaman, jumlah daun, luas daun, berat segar trubus per tanaman, berat kering trubus pertanaman, panjang akar, berat segar akar, rasio tajuk akar, berat kering akar dan indeks panen. Data hasil pengamatan kemudian dianalisis menggunakan sidik ragam Rancangan Acak Lengkap (RAL) faktorial, selanjutnya diuji lanjut dengan menggunakan Duncan Multiple Range Test (DMRT) dengan tingkat signifikan 5\% sesuai dengan petunjuk Gomez dan Gomez, (2010). Analisis data menggunakan program SAS 9.1.

\section{Hasil dan Pembahasan}

\subsection{Hasil}

\section{Parameter Lingkungan}

\section{a. Suhu Tanah}

Hasil sidik ragam (Anova) menunjukkan tidak terjadi interaksi antar takaran biochar dan kompos kirinyuh terhadap suhu tanah. Hasil pengamatan yang dipaparkan pada Tabel 1. menunjukkan bahwa suhu tanah tidak berbeda nyata antar perlakuan namun terdapat perbedaan peningkatan suhu tanah saat pengamatan 14 HST, 21 HST, 28 HST dan 35 HST, dimana suhu tanah tertinggi diperoleh pada perlakuan biochar $10 \mathrm{t} / \mathrm{ha}$ sedangkan takaran kompos kirinyuh yang berpengaruh menghasilkan suhu tanah tertinggi pada takaran 10 t/ha tetapi tidak berbeda nyata dengan takaran lainnya (Tabel 1).

Tabel 1. Suhu Tanah $\left({ }^{0} \mathrm{C}\right)$

\begin{tabular}{|c|c|c|c|c|c|c|c|}
\hline \multirow{2}{*}{$\begin{array}{c}\text { Waktu } \\
\text { Pengamatan } \\
\text { (HST) }\end{array}$} & \multirow{2}{*}{$\begin{array}{c}\text { Kompos } \\
\text { Kirinyuh } \\
(\mathrm{t} / \mathrm{ha})\end{array}$} & \multicolumn{5}{|c|}{ Takaran Biochar (t/ha) } & \multirow[b]{2}{*}{ Rerata } \\
\hline & & 0 & 2,5 & 5 & 7,5 & 10 & \\
\hline \multirow{4}{*}{14} & 0 & 35.53 & 34.13 & 34.33 & 35.6 & 34.13 & $34.74 \mathrm{a}$ \\
\hline & 5 & 34.13 & 36.56 & 35.93 & 34.43 & 33.66 & $34.94 \mathrm{a}$ \\
\hline & 10 & 34.60 & 35.13 & 35.83 & 36.3 & 34.86 & $35.34 \mathrm{a}$ \\
\hline & Rerata & $34.75 \mathrm{a}$ & $35.27 \mathrm{a}$ & $35.36 \mathrm{a}$ & $35.44 \mathrm{a}$ & $34.22 \mathrm{a}$ & $(-)$ \\
\hline \multirow{4}{*}{20} & 0 & 34.73 & 34.77 & 35.20 & 35.60 & 30.77 & $54.21 \mathrm{a}$ \\
\hline & 5 & 34.77 & 35.23 & 35.70 & 36.03 & 35.67 & $35.48 \mathrm{a}$ \\
\hline & 10 & 36.40 & 34.77 & 35.13 & 34.73 & 35.13 & $35.23 \mathrm{a}$ \\
\hline & Rerata & $35.30 \mathrm{a}$ & $34.92 \mathrm{a}$ & $35.34 \mathrm{a}$ & $35.46 \mathrm{a}$ & $67.19 \mathrm{a}$ & $(-)$ \\
\hline \multirow{4}{*}{28} & 0 & 34.73 & 35.83 & 35.33 & 33.67 & 35.83 & $35.08 \mathrm{a}$ \\
\hline & 5 & 35.83 & 35.23 & 36.47 & 39.73 & 35.20 & $36.49 \mathrm{a}$ \\
\hline & 10 & 34.57 & 36.13 & 35.67 & 34.87 & 36.33 & $35.51 \mathrm{a}$ \\
\hline & Rerata & $35.04 \mathrm{a}$ & $35.73 \mathrm{a}$ & $35.82 \mathrm{a}$ & $36.08 \mathrm{a}$ & $35.78 \mathrm{a}$ & $(-)$ \\
\hline \multirow{4}{*}{35} & $\overline{0}$ & 30.53 & 30.23 & 30.90 & 31.17 & 30.23 & $30.61 \mathrm{a}$ \\
\hline & 5 & 30.23 & 31.17 & 31.30 & 31.10 & 31.10 & $30.63 \mathrm{a}$ \\
\hline & 10 & 31.63 & 30.50 & 30.97 & 30.80 & 30.83 & $30.94 \mathrm{a}$ \\
\hline & Rerata & $30 \mathrm{a}$ & $30 \mathrm{a}$ & $31.05 \mathrm{a}$ & $31.02 \mathrm{a}$ & $30.72 \mathrm{a}$ & $(-)$ \\
\hline
\end{tabular}

Keterangan: Angka pada kolom dan baris yang diikuti huruf yang sama menunjukkan tidak berbeda nyata pada tingkat atau jenjang ( $\alpha$ ) $5 \%$ DMRT. (-): Tidak terjadi interaksi antar faktor. HST: Hari Setelah Tanam

\section{b. Kadar Lengas Tanah}

Hasil sidik ragam (Anova) menunjukkan bahwa tidak terjadi interaks antar pemberian takaran biochar dan kompos kirinyuh terhadap pengamatan kadar lengas tanah. Parameter kadar lengas tanah tidak menunjukkan beda nyata antar perlakuan,tetapi pada tabel 2 , dapat dilihat bahwa kadar lengas tanah paling tinggi diperoleh pada pemberian biochar 7,5 t/ha tetapi yang berbeda nyata dengan level takaran biochar $10 \mathrm{t} / \mathrm{ha}$. Sedangkan perlakuan kompos kirinyuh takaran 10 t/ha juga menghasilkan kadar lengas tanah yang cukup tinggi, dan tidak berbeda nyata dengan level takaran kompos kirinyuh lainnya (Tabel 2).

Tabel 2. Kadar Lengas Tanah (\%)

\begin{tabular}{ccccccc}
$\begin{array}{c}\text { Kompos } \\
\text { Kirinyuh } \\
(\mathrm{t} / \mathrm{ha})\end{array}$ & 0 & 2,5 & 5 & 7,5 & 10 & \\
\cline { 2 - 6 } & 47.083 & 45.297 & 40.000 & 48.210 & 45.757 & $45.269 \mathrm{a}$ \\
\hline 0 & 47.253 & 46.557 & 46.207 & 47.713 & 45.637 & $46.673 \mathrm{a}$ \\
5 & 49.430 & 47.020 & 35.537 & 61.950 & 44.520 & $47.691 \mathrm{a}$ \\
10 & $47.922 \mathrm{a}$ & 46.29 & & \multicolumn{5}{c}{ Biochar (t/ha) } \\
\hline
\end{tabular}

$\begin{array}{lllllllll}\text { Rerata } & 47.922 \mathrm{ab} & 46.29 \mathrm{ab} & 45.30 & \mathrm{~b} & 52.624 \mathrm{a} & 45.30 & \mathrm{ab} & (-)\end{array}$

Keterangan: Angka pada kolom dan baris yang diikuti huruf yang sama menunjukkan tidak berbeda nyata pada tingkat atau jenjang ( $\alpha$ ) $5 \%$ DMRT. (-) : Tidak terjadi interaksi antar faktor. HST: Hari Setelah Tanam

\section{c. Daya Hantar Listrik Tanah (DHL)}

Hasil sidik ragam (Anova) menunjukkan bahwa tidak terjadi interaksi antara takaran biochar dan kompos kirinyuh terhadap pengamatan DHL tanah. Hasil uji lanjut menunjukkan bahwa DHL tanah dengan pemberian biochar takaran $10 \mathrm{t} /$ ha menghasilkan DHL tanah paling tinggi yang berbeda nyata dengan takaran biochar 7,5 t/ha. Kompos kirinyuh menghasilkan DHL tertinggi pada takaran $10 \mathrm{t} / \mathrm{ha}$ tetapi tidak berbeda nyata dengan takaran lainnya (Tabel 3)

\section{d. $\mathrm{pH}$ Tanah}

Hasil sidik ragam (Anova) menunjukkan bahwa tidak terjadi interaksi antar pemberian biochar dan kompos kirinyuh terhadap $\mathrm{pH}$ tanah. Hasil uji lanjut menunjukkan perlakuan takaran biochar maupun perlakuan kompos kirinyuh tidak berpengaruh nyata. Data hasil pengamatan pada Tabel 4 menunjukkan bahwa $\mathrm{pH}$ tanah tertinggi diperoleh pada pemberian biochar
$7.5 \mathrm{t} / \mathrm{ha}$, sedangkan kompos kirinyuh yang memberikan $\mathrm{pH}$ tertinggi pada kontrol (0 t/ha)

Tabel 3. Daya Hantar Listrik Tanah $(\mu \mathrm{S} / \mathrm{cm})$

\begin{tabular}{|c|c|c|c|c|c|c|}
\hline \multirow{2}{*}{$\begin{array}{c}\text { Kompos } \\
\text { Kirinyuh } \\
\text { (t/ha) }\end{array}$} & \multicolumn{5}{|c|}{$\operatorname{Biochar}(\mathrm{t} / \mathrm{ha})$} & \multirow[b]{2}{*}{ Rerata } \\
\hline & 0 & 2,5 & 5 & 7,5 & 10 & \\
\hline 0 & 515.44 & 517.00 & 587.78 & 479.78 & 623.33 & $544.67 \mathrm{a}$ \\
\hline 5 & 537.33 & 545.00 & 524.55 & 543.22 & 562.89 & $542.60 \mathrm{a}$ \\
\hline 10 & 610.22 & 564.89 & 584.78 & 485.44 & 561.55 & $561.38 \mathrm{a}$ \\
\hline Rerata & $554.33 \mathrm{ab}$ & $542.30 \mathrm{ab}$ & $565.70 \mathrm{ab}$ & $502.81 \mathrm{~b}$ & $582.59 \mathrm{a}$ & $(-)$ \\
\hline
\end{tabular}

Keterangan: Angka pada kolom dan baris yang diikuti huruf yang sama menunjukkan tidak berbeda nyata pada tingkat atau jenjang ( $\alpha$ ) $5 \%$ DMRT. (- ): Tidak terjadi interaksi antar faktor. HST: Hari Setelah Tanam

Tabel 4. pH Tanah

\begin{tabular}{ccccccc}
$\begin{array}{c}\text { Kompos } \\
\text { Kirinyuh } \\
\text { (t/ha) }\end{array}$ & 0 & 2,5 & 5 & 7,5 & 10 & Rerata \\
\cline { 2 - 5 } & 7.78 & 7.9 & 7.84 & 7.88 & 7.95 & $7.87 \mathrm{a}$ \\
5 & 7.81 & 7.89 & 7.85 & 7.84 & 7.88 & $7.85 \mathrm{a}$ \\
10 & 7.85 & 7.78 & 7.82 & 7.89 & 7.87 & $7.31 \mathrm{a}$ \\
\hline Rerata & $7.80 \mathrm{a}$ & $7.86 \mathrm{a}$ & $7.84 \mathrm{a}$ & $7.87 \mathrm{a}$ & $7.01 \mathrm{a}$ & $(-)$
\end{tabular}

Keterangan: Angka pada kolom dan baris yang diikuti huruf yang sama menunjukkan tidak berbeda nyata pada tingkat atau jenjang ( $\alpha$ ) $5 \%$ DMRT. (-): Tidak terjadi interaksi antar faktor. HST : Hari Setelah Tanam

e. Berat Volume Tanah

Hasil sidik ragam (Anova) menunjukkan bahwa tidak terjadi interaksi antar pemberian biochar dan kompos kirinyuh pada pengamatan berat volume tanah. Hasil uji lanjut menunjukkan tidak ada pengaruh nyata pada setiap perlakuan. Pada Tabel 5 menunjukkan bahwa berat volume tanah cenderung lebih rendah pada takaran $5 \mathrm{t} / \mathrm{ha}$ dan $10 \mathrm{t} / \mathrm{ha}$. Sedangkan kompos kirinyuh cenderung meningkatkan berat volume tanah lebih tinggi pada takaran $5 \mathrm{t} /$ ha dibandingkan takaran $10 \mathrm{t} / \mathrm{ha}$ dan tanpa kompos kirinyuh.

Tabel 5. Berat Volume Tanah $\left(\mathrm{g} / \mathrm{cm}^{3}\right)$

\begin{tabular}{ccccccc}
\hline Kompos & \multicolumn{7}{c}{ Biochar (t/ha) } & \multirow{2}{*}{ Rerata } \\
\cline { 2 - 7 } Kirinyuh (t/ha) & 0 & 2,5 & 5 & 7,5 & 10 & \\
\hline 0 & 1.373 & 1.183 & 1.303 & 1.563 & 1.113 & $1.307 \mathrm{a}$ \\
5 & 1.220 & 1.290 & 0.946 & 1.260 & 1.216 & $1.186 \mathrm{a}$ \\
10 & 1.073 & 1.360 & 0.966 & 0.886 & 0.953 & $1.048 \mathrm{a}$ \\
\hline Rerata & $1.222 \mathrm{a}$ & $1.277 \mathrm{a}$ & $1.072 \mathrm{a}$ & $1.236 \mathrm{a}$ & $1.094 \mathrm{a}$ & $(-)$ \\
\hline
\end{tabular}

Keterangan: Angka pada kolom dan baris yang diikuti huruf yang sama menunjukkan tidak berbeda nyata pada tingkat atau jenjang ( $\alpha$ ) $5 \%$ DMRT. (-) : Tidak terjadi interaksi antar faktor. HST: Hari Setelah Tanam

\section{Parameter Pertumbuhan}

\section{a. Tinggi Tanaman}

Hasil sidik ragam (Anova) menunjukkan bahwa tidak terjadi interaksi antara pemberian biochar dan kompos kirinyuh terhadap tinggi tanaman selada darat pada umur $14,21,28,35,42 \mathrm{HST}$, perlakuan biochar dan kompas kirinyuh menyebabkan terjadinya peningkatan tinggi tanaman. Tinggi tanaman pada umur 14, 21, dan 28 HST menunjukkan bahwa pada takaran biochar 7,5 t/ha dan $0 \mathrm{t} / \mathrm{ha}$ kompos kirinyuh terjadi peningkatan tinggi tanaman. Sedangkan tinggi tanaman pada umur 35 dan 42 HST menunjukkan bahwa pada takatan biochar 2,5 t/ha dan kompas kirinyuh 10 t/ha yang terjadi peningkatan tinggi tanaman. Pemberian biochar dan kompas kirinyuh dimana pertumbuhan cenderung lebih cepat tinggi (Tabel 6).

\begin{tabular}{|c|c|c|c|c|c|c|c|}
\hline \multirow{2}{*}{$\begin{array}{c}\text { Waktu } \\
\text { Pengamatan } \\
\text { (HST) }\end{array}$} & \multirow{2}{*}{$\begin{array}{c}\text { Kompos } \\
\text { Kirinyuh } \\
\text { (t/ha) }\end{array}$} & \multicolumn{5}{|c|}{ Takaran Biochar (t/ha) } & \multirow[b]{2}{*}{ Rerata } \\
\hline & & 0 & 2,5 & 5 & 7,5 & 10 & \\
\hline \multirow{4}{*}{14} & 0 & 6.9 & 8.1 & 5.3 & 7.6 & 5.8 & $6.76 \mathrm{a}$ \\
\hline & 5 & 6.2 & 6.1 & 5.8 & 6.2 & 7.7 & $6.42 \mathrm{a}$ \\
\hline & 10 & 5.8 & 6,0 & 7.2 & 7.6 & 6.4 & $6.63 \mathrm{a}$ \\
\hline & Rerata & $6.34 \mathrm{a}$ & $6.76 \mathrm{a}$ & $6.13 \mathrm{a}$ & $7.15 \mathrm{a}$ & $6.63 \mathrm{a}$ & $(-)$ \\
\hline \multirow{4}{*}{21} & 0 & 9.8 & 10.5 & 8.5 & 10.0 & 9.3 & $9.63 \mathrm{a}$ \\
\hline & 5 & 9.0 & 9.1 & 10.0 & 9.1 & 10.6 & $9.60 \mathrm{a}$ \\
\hline & 10 & 9.0 & 9.3 & 8.5 & 10.6 & 8.3 & $9.16 \mathrm{a}$ \\
\hline & Rerata & $9.27 \mathrm{ab}$ & $9.66 \mathrm{ab}$ & $8.72 \mathrm{~b}$ & $10.22 \mathrm{a}$ & $9.44 \mathrm{ab}$ & $(-)$ \\
\hline \multirow{4}{*}{28} & 0 & 11.23 & 11.30 & 10.73 & 11.00 & 10.43 & $10.94 \mathrm{a}$ \\
\hline & 5 & 9.93 & 10.93 & 10.70 & 10.73 & 11.50 & $10.76 \mathrm{a}$ \\
\hline & 10 & 10.66 & 11.53 & 10.16 & 12.03 & 10.30 & $10.94 \mathrm{a}$ \\
\hline & Rerata & $10.61 \mathrm{a}$ & $11.25 \mathrm{a}$ & $10.53 \mathrm{a}$ & $11.25 \mathrm{a}$ & $10.74 \mathrm{a}$ & $(-)$ \\
\hline \multirow{4}{*}{35} & 0 & 13.56 & 12.93 & 13.00 & 13.20 & 12.66 & $13.07 \mathrm{a}$ \\
\hline & 5 & 12.73 & 13.50 & 12.13 & 12.56 & 13.06 & $12.80 \mathrm{a}$ \\
\hline & 10 & 14.40 & 14.03 & 12.73 & 13.66 & 12.53 & $13.46 \mathrm{a}$ \\
\hline & Rerata & $13.56 \mathrm{a}$ & $13.48 \mathrm{a}$ & $12.60 \mathrm{a}$ & $13.14 \mathrm{a}$ & $12.75 \mathrm{a}$ & $(-)$ \\
\hline \multirow{4}{*}{42} & 0 & 14.00 & 13.50 & 13.80 & 14.30 & 13.16 & $13.75 \mathrm{ab}$ \\
\hline & 5 & 13.06 & 14.40 & 13.26 & 13.10 & 13.50 & $13.46 \mathrm{~b}$ \\
\hline & 10 & 15.30 & 14.53 & 13.43 & 14.86 & 13.066 & $14.24 \mathrm{a}$ \\
\hline & Rerata & $14.12 \mathrm{a}$ & $14.14 \mathrm{a}$ & $13.50 \mathrm{a}$ & $14.08 \mathrm{a}$ & $13.24 \mathrm{c}$ & $(-)$ \\
\hline
\end{tabular}




\section{b. Jumlah Daun}

Hasil sidik ragam (Anova) menunjukkan tidak terjadi interaksi antar perlakuan biochar dan takaran kompos kirinyuh terhadap pengamatan jumlah daun, pada tanaman selada darat. Data pada tabel 7 menunjukkan bahwa pertumbuhan jumlah daun cenderung lebih cepat dan terbanyak pada pemberian biochar 2,5 t/ha dan kompos kirinyuh pada takaran $10 \mathrm{t} / \mathrm{ha}$ pada waktu pengamatan $42 \mathrm{HST}$

Tabel 7. Jumlah Daun (Helai)

\begin{tabular}{|c|c|c|c|c|c|c|c|}
\hline \multirow{2}{*}{$\begin{array}{c}\text { Waktu Pengamatan } \\
\text { (HST) }\end{array}$} & \multirow{2}{*}{$\begin{array}{c}\text { Takaran } \\
\text { Kompos Kirinyuh } \\
\text { (t/ha) }\end{array}$} & \multicolumn{5}{|c|}{ Takaran Biochar (t/ha) } & \multirow[b]{2}{*}{ Rerata } \\
\hline & & 0 & 2,5 & 5 & 7,5 & 10 & \\
\hline \multirow{3}{*}{14} & 0 & 2 & 3 & 2 & 2 & 2 & $2 a$ \\
\hline & 5 & 2 & 2 & 2 & 2 & 2 & $2 a$ \\
\hline & 10 & 2 & 2 & 2 & 2 & 3 & $2 a$ \\
\hline \multirow[t]{2}{*}{ Rerata } & & $2 a$ & $2 a$ & $2 a$ & $2 a$ & $2 a$ & $(-)$ \\
\hline & 0 & 3 & 4 & 3 & 3 & 3 & $3 a$ \\
\hline \multirow[t]{2}{*}{21} & 5 & 3 & 3 & 3 & 4 & 4 & $3 a$ \\
\hline & 10 & 4 & 4 & 3 & 4 & 3 & $3 a$ \\
\hline \multirow[t]{2}{*}{ Rerata } & & $3 \mathrm{ab}$ & $4 \mathrm{a}$ & $3 \mathrm{~b}$ & $3 \mathrm{ab}$ & $3 a b$ & $(-)$ \\
\hline & 0 & 4 & 5 & 4 & 4 & 4 & $4 a$ \\
\hline \multirow{2}{*}{28} & 5 & 4 & 5 & 5 & 5 & 4 & $4 \mathrm{a}$ \\
\hline & 10 & 4 & 5 & 4 & 5 & 5 & $4 \mathrm{a}$ \\
\hline \multirow[t]{2}{*}{ Rerata } & & $4 a$ & $5 a$ & $4 a$ & $4 \mathrm{a}$ & $4 \mathrm{a}$ & $(-)$ \\
\hline & 0 & 5 & 5 & 5 & 5 & 5 & $5 a$ \\
\hline \multirow[t]{2}{*}{35} & 5 & 5 & 5 & 4 & 5 & 5 & $5 a$ \\
\hline & 10 & 5 & 5 & 5 & 5 & 5 & $5 \mathrm{a}$ \\
\hline \multirow[t]{2}{*}{ Rerata } & & $5 \mathrm{a}$ & $5 \mathrm{a}$ & $4 \mathrm{a}$ & $5 a$ & $5 \mathrm{a}$ & $(-)$ \\
\hline & 0 & 7 & 7 & 6 & 6 & 6 & $6 a$ \\
\hline \multirow[t]{2}{*}{42} & 5 & 6 & 7 & 6 & 6 & 7 & $6 a$ \\
\hline & 10 & 7 & 7 & 6 & 7 & 6 & $6 \mathrm{a}$ \\
\hline
\end{tabular}

Keterangan: Angka pada kolom dan baris yang diikuti huruf yang sama menunjukkan tidak berbeda nyata pada tingkat atau jenjang ( $\alpha$ ) $5 \%$ DMRT. (-): Tidak terjadi interaksi antar faktor. HST: Hari Setelah Tanam

\section{c. Luas Daun}

Hasil sidik ragam (Anova) menunjukkan tidak terjadi interaksi antar pemberian takaran biochar dan kompos kirinyuh terhadap pengamatan luas daun selada darat. Pada tabel 8 menunjukkan bahwa hasil pengamatan luas daun tanaman selada darat yang memiliki daun paling besar diperoleh pada perlakuan biochar $0 \mathrm{t} / \mathrm{ha}$ yang tidak berbeda nyata dengan perlakuan lainnya. Sedangkan perlakuan kompos kirinyuh 10 t/ha menghasilkan daun yang lebih luas dibandingkan takaran $5 \mathrm{t} / \mathrm{ha}$ tetapi tidak lebih tinggi dari pada kontrol (0 t/ha).

Tabel 8. Luas Daun $\left(\mathrm{cm}^{2}\right)$

\begin{tabular}{|c|c|c|c|c|c|c|c|}
\hline \multirow{2}{*}{$\begin{array}{c}\text { Waktu } \\
\text { Pengamatan } \\
\text { (HST) }\end{array}$} & \multirow{2}{*}{$\begin{array}{c}\text { Takaran } \\
\text { Kompos } \\
\text { Kirinyuh } \\
\text { (t/ha) }\end{array}$} & \multicolumn{4}{|c|}{ Takaran Biochar (t/ha) } & \multirow[b]{2}{*}{10} & \multirow{2}{*}{ Rerata } \\
\hline & & 0 & 2,5 & 5 & 7,5 & & \\
\hline \multirow{3}{*}{42} & 0 & 17.8 & 15. & 19. & 16.9 & 16.8 & $17.19 \mathrm{a}$ \\
\hline & 5 & 18.7 & 13. & 11. & 17.9 & 10.4 & $14.89 \mathrm{a}$ \\
\hline & 10 & 17.4 & 18.8 & 10.7 & 18.6 & 14.2 & $15.78 \mathrm{a}$ \\
\hline Rerata & & $18.0 \mathrm{a}$ & $15.8 \mathrm{a}$ & $13.9 \mathrm{a}$ & $17.8 \mathrm{a}$ & $13.4 \mathrm{a}$ & $(-)$ \\
\hline
\end{tabular}

Keterangan: Angka pada kolom dan baris yang diikuti huruf yang sama menunjukkan tidak berbeda nyata pada tingkat atau jenjang ( $\alpha$ ) $5 \%$ DMRT. (-): Tidak terjadi interaksi antar faktor. HST: Hari Setelah Tanam

\section{Parameter Hasil}

a. Berat Segar Trubus Per Tanaman

Hasil sidik ragam (Anova) menunjukkan tidak terjadi interaksi antar takaran biochar sekam padi dan kompos kirinyuh pada berat segar trubus per tanaman. Data pada tabel 9 menunjukkan hasil pengamatan berat segar trubus per tanaman, dimana tanaman selada darat yang diberi perlakuan biochar 2,5 t/ha memiliki berat segar trubus paling berat dibanding dengan takaran biochar lainnya, sedangkan perlakuan kompos kirinyuh $10 \mathrm{t} / \mathrm{ha}$ memberikan hasil berat segar trubus per tanaman terberat berbeda dengan takaran lainnya.

Tabel 9. Berat Segar Trubus Per Tanaman(g)

\begin{tabular}{|c|c|c|c|c|c|c|c|}
\hline \multirow{2}{*}{$\begin{array}{c}\text { Waktu } \\
\text { Pengamatan } \\
\text { (HST) }\end{array}$} & \multirow{2}{*}{$\begin{array}{c}\text { Takaran } \\
\text { Kompos } \\
\text { Kirinyuh } \\
(\mathrm{t} / \mathrm{ha})\end{array}$} & \multicolumn{4}{|c|}{ Takaran Biochar (t/ha) } & \multirow[b]{2}{*}{10} & \multirow{2}{*}{ Rerata } \\
\hline & & 0 & 2,5 & 5 & 7,5 & & \\
\hline \multirow{3}{*}{42} & 0 & 15.970 & 16.917 & 4.527 & 12.467 & 9.553 & $13.88 \mathrm{a}$ \\
\hline & 5 & 12.290 & 15.717 & 15.333 & 13.267 & 11.880 & $13.69 \mathrm{a}$ \\
\hline & 10 & 15.097 & 17.303 & 14.517 & 15.040 & 13.613 & $15.11 \mathrm{a}$ \\
\hline Rerata & & $14.45 \mathrm{a}$ & $16.64 \mathrm{a}$ & $14.79 \mathrm{a}$ & $13.59 \mathrm{a}$ & $11.68 \mathrm{a}$ & $(-)$ \\
\hline
\end{tabular}

Hasil Penelitian terdahulu Opat (2017) menunjukkan bahwa berat segar trubus per tanaman diperoleh pada takaran 0 t/ha (Gambar 1). Hal ini berbanding terbalik dengan hasil penelitian ini, yang mana dengan pemberian 2,5 t/ha memberikan berat segar trubus tertinggi. Dapat dikatakan bahwa biochar sebagai bahan pembenah tanah masih terjadi proses penguraian sehingga dapat digunakan dengan baik untuk musim penanaman kedua.

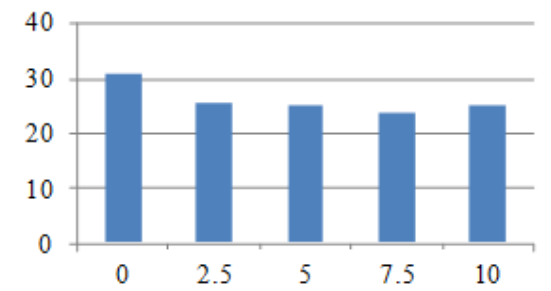

Gambar 1. Berat Segar Trubus Pada Penelitian Sebelumnya (Opat, 2017)

b. Berat Kering PerTanaman

Hasil sidik ragam (Anova) menunjukkan tidak terjadi interaksi antar perlakuan takaran biochar dan kompos kirinyuh pada berat kering daun. Pada Tabel 10 perlakuan biochar 2,5 t/ha memberikan berat kering trubus terberat tetapi tidak berbeda nyata dengan perlakuan biochar pada takaran lainnya. Pemberian kompos kirinyuh 10 t/ha menghasilkan berat kering daun terberat tetapi tidak beda nyata dibanding dengan pemberian kompos kirinyuh pada takaran yang lain (Tabel 10).

Tabel 10. Berat Kering Trubus Per Tanaman (g)

\begin{tabular}{ccccccccc}
\hline \multirow{2}{*}{$\begin{array}{c}\text { Waktu } \\
\text { Pengamatan } \\
(\text { HST) }\end{array}$} & $\begin{array}{c}\text { Takaran } \\
\text { Kompos } \\
\text { Kirinyuh } \\
\text { (t/ha) }\end{array}$ & \multicolumn{3}{c}{ Takaran Biochar (t/ha) } & & Rerata \\
\cline { 3 - 7 } & 0 & 7.00 & 7.66 & 6.66 & 6.33 & 6.00 & $6.73 \mathrm{a}$ \\
& 42 & 5 & 6.00 & 7.33 & 6.00 & 6.66 & 7.33 & $6.66 \mathrm{a}$ \\
& 10 & 7.00 & 7.66 & 6.66 & 7.33 & 6.00 & $6.93 \mathrm{a}$ \\
\hline Rerata & & $6.66 \mathrm{a}$ & $7.55 \mathrm{a}$ & $6.44 \mathrm{a}$ & $6.77 \mathrm{a}$ & $6.44 \mathrm{a}$ & $(-)$ \\
\hline
\end{tabular}

Keterangan: Angka pada kolom dan baris yang diikuti huruf yang sama menunjukkan tidak berbeda nyata pada tingkat atau jenjang ( $\alpha$ ) $5 \%$ DMRT. (-): Tidak terjadi interaksi antar faktor. HST: Hari Setelah Tanam

\section{c. Panjang Akar}

Hasil sidik ragam (Anova) menunjukkan tidak terjadi interaksi antar perlakuan takaran biochar dan kompos kirinyuh pada pengamatan panjang akar. Hasil pengamatan dapat dilihat pada tabel 11 panjang akar selada darat pada pemberian takaran biochar 2,5 t/ha yang memiliki akar terpanjang dibandingkan takaran lainnya, sedangkan pada perlakuan kompos kirinyuh, takaran $10 \mathrm{t} / \mathrm{ha}$ menghasilkan akar tanaman selada darat terpanjang. Walaupun demikian baik biochar maupun kompos kirinyuh keduanya tidak menunjukkan perbedaan yang nyata pada semua level perlakuannya

\section{d. Berat Segar Akar}

Hasil sidik ragam (Anova) menunjukkan tidak terjadi interaksi antara takaran biochar dan kompos kirinyuh pada pengamatan berat segar akar. Hasil uji lanjut pada tabel 12 menunjukkan tidak ada beda nyata antara pemberian takaran biochar dan kompos kirinyuh. Pengaruh biochar pada takaran 2,5 t/ha menghasilkan akar segar lebih berat dibandingkan takaran lainnya. Kompos kirinyuh 10 t/ha menghasilkan akar segar yang lebih berat dibandingkan takaran lainnya

\section{Tabel 11. Panjang Akar (cm)}

\begin{tabular}{cccccccc}
\hline \multirow{2}{*}{$\begin{array}{c}\text { Waktu } \\
\text { Pengamatan } \\
(\text { HST) }\end{array}$} & $\begin{array}{c}\text { Takaran } \\
\text { Kompos }\end{array}$ & \multicolumn{7}{c}{ Takaran Biochar (t/ha) } \\
\cline { 3 - 8 } & $\begin{array}{c}\text { Kinyuh } \\
(\mathrm{t} / \mathrm{ha})\end{array}$ & 0 & 2,5 & 5 & 7,5 & 10 & \\
\hline & 0 & 15.97 & 16.92 & 14.53 & 12.47 & 9.55 & $13.88 \mathrm{a}$ \\
42 & 5 & 12.29 & 15.72 & 15.33 & 13.27 & 11.88 & $13.69 \mathrm{a}$ \\
& 10 & 15.10 & 17.30 & 14.52 & 15.04 & 13.61 & $15.11 \mathrm{a}$ \\
\hline Rerata & & $14.45 \mathrm{a}$ & $16.64 \mathrm{a}$ & $14.79 \mathrm{a}$ & $13.59 \mathrm{a}$ & $11.68 \mathrm{a}$ & $(-)$ \\
\hline
\end{tabular}

Keterangan: Angka pada kolom dan baris yang diikuti huruf yang sama menunjukkan tidak berbeda nyata pada tingkat atau jenjang ( $\alpha$ ) $5 \%$ DMRT. (-): Tidak terjadi interaksi antar faktor. HST: Hari Setelah Tanam

\section{e. Rasio Tajuk Akar}

Hasil sidik ragam (Anova) menunjukkan tidak terjadi interaksi antara takaran biochar dan kompos kirinyuh pada pengamatan rasio tajuk akar. Hasil uji lanjut pada tabel 13 menunjukkan tidak ada beda nyata antara masing-masing level perlakuan, baik pada takaran biochar maupun kompos kirinyuh. Rasio tajuk akar pada pemberian biochar $5 \mathrm{t} /$ ha memberikan rasio tajuk akar tertinggi, sedangkan pemberian kompos kirinyuh yang memberikan nilai rasio tajuk akar tertinggi pada control atau tanpa kompos kirinyuh. 


\section{f. Indeks Panen}

Hasil sidik ragam (Anova) menunjukkan tidak terjadi interaksi antar perlakuan takaran biochar sekam padi dan takaran kompos kirinyuh terhadap Indeks Panen. Pada tabel 14 dapat dilihat bahwa pengaruh takaran biochar maupun takaran kompos kirinyuh tidak nyata mempengaruhi indeks panen. Indeks panen tertinggi diperoleh pada pemberian biochar sekampadi $5 \mathrm{t} / \mathrm{ha}$. Demikian pula pemberian kompos kirinyuh 5 t/ha dapat memberikan nilai indeks panen tertinggi.

\section{Tabel 12. Berat Segar Akar (g)}

\begin{tabular}{ccccccccc}
\hline \multirow{2}{*}{$\begin{array}{c}\text { Waktu } \\
\text { Pengamatan } \\
(\text { HST })\end{array}$} & $\begin{array}{c}\text { Takaran } \\
\text { Kompos }\end{array}$ & \multicolumn{9}{c}{ Takaran Biochar (t/ha) } \\
\cline { 3 - 9 } & $\begin{array}{c}\text { Kirinyuh } \\
\text { (t/ha) }\end{array}$ & 0 & 2,5 & 5 & 7,5 & 10 & \\
\hline & 0 & 1.60 & 1.91 & 0.74 & 1.36 & 1.21 & $1.33 \mathrm{a}$ \\
42 & 5 & 0.98 & 1.45 & 1.04 & 1.44 & 1.27 & $1.23 \mathrm{a}$ \\
& 10 & 1.94 & 1.91 & 1.68 & 1.73 & 1.16 & $1.68 \mathrm{a}$ \\
\hline Rerata & & $1.50 \mathrm{a}$ & $1.70 \mathrm{a}$ & $1.15 \mathrm{a}$ & $1.51 \mathrm{a}$ & $1.21 \mathrm{a}$ & $(-)$
\end{tabular}

Keterangan: Angka pada kolom dan baris yang diikuti huruf yang sama menunjukkan tidak berbeda nyata pada tingkat atau jenjang ( $\alpha$ ) $5 \%$ DMRT. (-) : Tidak terjadi interaksi antar faktor. HST: Hari Setelah Tanam

Tabel 13. Rasio Tajuk Akar

\begin{tabular}{|c|c|c|c|c|c|c|c|}
\hline \multirow{2}{*}{$\begin{array}{c}\text { Waktu } \\
\text { Pengamatan } \\
\text { (HST) }\end{array}$} & \multirow{2}{*}{$\begin{array}{c}\text { Takaran } \\
\text { Kompos } \\
\text { Kirinyuh } \\
\text { (t/ha) }\end{array}$} & \multicolumn{4}{|c|}{ Takaran Biochar (t/ha) } & \multirow[b]{2}{*}{10} & \multirow[b]{2}{*}{ Rerata } \\
\hline & & 0 & 2,5 & 5 & 7,5 & & \\
\hline \multirow{3}{*}{42} & 0 & 10.38 & 10.11 & 10.05 & 10.25 & 7.93 & $17.28 \mathrm{a}$ \\
\hline & 5 & 15.52 & 11.24 & 19.23 & 11.19 & 9.39 & $13.33 \mathrm{a}$ \\
\hline & 10 & 7.93 & 10.25 & 8.58 & 9.45 & 12.49 & $9.74 \mathrm{a}$ \\
\hline Rerata & & $11.27 \mathrm{a}$ & $10.53 \mathrm{a}$ & $25.18 \mathrm{a}$ & $10.29 \mathrm{a}$ & $9.93 \mathrm{a}$ & $(-)$ \\
\hline
\end{tabular}

Keterangan: Angka pada kolom dan baris yang diikuti huruf yang sama menunjukkan tidak berbeda nyata pada tingkat atau jenjang (a) $5 \%$ DMRT. (-): Tidak terjadi interaksi antar faktor. HST: Hari Setelah Tanam

\begin{tabular}{|c|c|c|c|c|c|c|}
\hline \multirow{2}{*}{$\begin{array}{c}\text { Waktu } \\
\text { Pengamatan } \\
\text { (HST) }\end{array}$} & \multirow{2}{*}{$\begin{array}{c}\text { Takaran } \\
\text { Kompos } \\
\text { Kirinyuh } \\
\text { (t/ha) }\end{array}$} & \multicolumn{5}{|c|}{ Takaran Biochar (t/ha) } \\
\hline & & 0 & 2,5 & 5 & 7,5 & - Rerata \\
\hline \multirow{3}{*}{43} & 0 & 90.98 & 92.82 & 92.62 & 90.63 & $88.6690 .68 \mathrm{a}$ \\
\hline & 5 & 90.50 & 91.64 & 93.12 & 89.73 & $90.1891 .50 \mathrm{a}$ \\
\hline & 10 & 88.74 & 90.71 & 89.42 & 89.73 & $92.3190 .18 \mathrm{a}$ \\
\hline Rerata & & $90.84 \mathrm{a}$ & $90.95 \mathrm{a}$ & $91.72 \mathrm{a}$ & $90.03 \mathrm{a}$ & 90.38 a $\quad(-)$ \\
\hline
\end{tabular}

Keterangan: Angka pada kolom dan baris yang diikutihuruf yang sama menunjukkan tidak berbeda nyata pada tingkat atau jenjang (a) $5 \%$ DMRT. (-): Tidak terjadi interaksi antar faktor. HST: Hari Setelah Tanam

\subsection{Pembahasan}

Hasil penelitian menunjukkan bahwa pertumbuhan tanaman yang baik menghasilkan berat segar trubus dan berat kering trubus pertanaman meningkat Hal ini nampak pada pengaruh perlakuan biochar 2,5 t/ha menghasilkan berat segar trubus $16.64 \mathrm{~g} /$ tanaman, dan perlakuan kompos kirinyuh $10 \mathrm{t} / \mathrm{ha}$ menghasilkan berat segar trubus $15,11 \mathrm{~g} /$ tanaman. Selanjutnya berat kering trubus7,55 g/tanaman pada perlakuan biochar 2,5 t/ha, dan pada perlakuan kompos kirinyuh $10 \mathrm{t} / \mathrm{ha}$ memperoleh $6,93 \mathrm{~g} /$ tanaman. Pada penelitian yang dilakukan sebelumnya oleh Opat (2017), perlakuan tanpa (0 t/ha) biochar menghasilkan trubus $30 \mathrm{~g} /$ tanaman dan kompos kirinyuh menghasilkan trubus $28,09 \mathrm{~g} /$ tanaman dengan berat kering trubus pada perlakukan tanpa biochar 2,63 g/tanaman, perlakuan kompos kirinyuh 10 t/ha menghasilkan berat kering daun $2,56 \mathrm{~g} /$ tanaman tetapi tidak berbeda nyata dengan takaran $10 \mathrm{t} / \mathrm{ha}$ yang menghasilkan berat kering daun 2,51 g/tanaman. Dengan demikian dapat dikatakan bahwa penggunaan biochar dapat mempertahankan produktivitas tanah yang ditunjukan pada hasil tanaman selada darat. Hal ini disebabkan adanya biochar sekam padi dan kompos kirinyuh pada media tanam mempengaruhi parameter lingkungan tumbuh tanaman selada darat meskipun tidak terjadi interaksi antara kedua perlakuan tersebut. Pengaruh utama pada perlakuan biochar dapat memperbaiki sifat fisik dan kimia tanah dimana dari hasil penelitian ini biochar mampu menurunkan suhu tanah hingga13.24 ${ }^{0} \mathrm{C}$ pada takaran $10 \mathrm{t} / \mathrm{ha}$, mampu meningkatkan DHL tanah $45.30 \mu \mathrm{S} / \mathrm{c}$ pada takaran $10 \mathrm{t} / \mathrm{ha}$, dapat menurunkan $\mathrm{pH}$ tanah 7.01 pada takaran $10 \mathrm{t} / \mathrm{ha}$ dan mampu meningkatkan berat volume tanah $1.094 \mathrm{~g} / \mathrm{cm}^{3}$ pada takaran $10 \mathrm{t} / \mathrm{ha}$. Kapasitas biochar mengikat air dipengaruhi terutama oleh karakteristik biochar (volume pori, hidrofobisitas luas permukaan spesifik, komposisi kimia dan lainnya yang ditentukan oleh bahan baku, suhu pirolisis) dan kondisi lingkungan (jenis tanah dan faktor iklim) dimana biochar diaplikasikan (Basso dkk., 2017), sehingga menyebabkan suhu tanah menurun. Biochar juga meningkatkan daya hantar listrik tanah (Chintala dkk., 2013), meningkatkan kapasitas tukar kation (Hossain dkk., 2010) meningkatkan kemampuan tanah mengikat air (Novak dkk., 2009; Laird dkk., 2010). Pada Faktor pertumbuhan juga terlihat adanya pengaruh dari biochar dan kompos kirinyuh yang dapa diexpresikan dalam bentuk tinggi tanaman, dimana biochar dengan takaran 10 t/ha dapat Sedangkan untuk parameter jumlah daun, biochar dan kompos kirinyuh memberikan efek yang sama dimana biochar dengan takaran 10 t/ha dapat meningkatkan jumlah daun dan berbeda nyata dengan kontrol pada pengamatan 14 dan 21 HST. Berat segar trubus per tanaman, berat kering trubus per tanaman, panjang akar, berat segar akar, berat kering akar sangat mempengaruhi indeks panen diperoleh pada takaran biochar $10 \mathrm{t} / \mathrm{ha}$ memperoleh nilai tertinggi dan takaran kompos kirinyuh $5 \mathrm{t} / \mathrm{ha}$ memberikan nilai tertinggi. Pada takaran antara 5-10 t/ha, baik biochar maupun kompos kirinyuh menghasilkan berat segar yang tidak berbeda nyata. Biochar pada takaran 2,5 t/ha menghasilkan trubus segar terberat yaitu16,64 g/tanaman. Kompos Kirinyuh dengan takaran 10 t/ha menghasilkan trubus segar seberat $15,11 \mathrm{~g} /$ tanaman lebih tinggi dari pada hasil tahun pertama ( $0 \mathrm{~g} /$ tanaman $)$. Hasil tersebut menunjukkan adanya aging effect aplikasi biochar sekam padi dan kompos kirinyuh terhadap pertumbuhan dan hasil selada darat

\section{Simpulan}

Berdasarkan hasil penelitian disimbulkan bahwa tidak terjadi interaksi antar parameter, baik pada parameter lingkungan, parameter pertumbuhan maupun parameter hasil pada musim tanam kedua. Pengamatan parameter hasil berat segar trubus per tanaman menunjukkan bahwa pemberian biochar sekam padi $2,5 \mathrm{t} /$ ha pada tanah vertisol tidak berpengaruh nyata terhadap hasil Selada darat (Lactuca sativa, L.). Akan tetapi pada pemberian kompos kirinyuh 10 t/ha menghasilkan trubus segar yang lebih berat.

\section{Pustaka}

Anas, I., D. Utami, T. Yuliawati, T. Muluk 2003. Lobak (Raphinus spinosum) dan bayam (Amaranthus spp.) sebagai penggant tanaman Cress (Lepidum sativum) dalam pengujian tingkat kematangan kompos. J. Penelitian Pertanian. 22 (1) : 34-40.

Basso, A.S., Miguez, F. E., Laird, D. A., Horton, R., Westgate, M. 2013. Assessing potential of biochar for increasing water holding capacity of sandysoils. GCB Bioenergy 5:132-143.

Basuki, A., Aditya Sumanegara D.,Dan Sinambela D.1994. The Gunung Pongkor Gold-Silver Deposit, West Jawa, Indonesia. Journal Ofgeochemical Exploration 50 (1994)P 371-391.

Chintala, R., J. Mollinedo, T. E. Schumacher, D. D. Malo, and J. L. Julson. 2013. Effect of biochars on chemical properties of acidic soil. Arch. Agron. Soil Sci. 1-12.

Gani, A. 2009. Multiguna arang -hayati biochar. Balai besar penelitian tanaman padi. warta penelitian dan pengembangan pertanian. 31:15-16.

Gani, A. 2010. Multiguna Arang - Hayati Biochar. Balai Besar Penelitian Tanaman Padi. SinarTani. Edisi 13-19: 1-4.

Gomez, K.A. dan Gomez A.A. 2010. Prosedur Statistik untuk Penelitian Pertanian Edisi ke 2. Jakarta (Indonesia): UI Press.

Hossain, M. K., Strezov, V., Chan,K.Y., Nelson, P. F. 2010. Agronomic properties of wastewatersludge biochar and bioavailability of metals in production of cherrytomato (Lycopersicon esculentum). Chemosphere 78: 1167-1171

Mia S., Dijkstra F.A., Singh B. 2016. Long-Term Aging of Biochar: A Molecular Under standing With Agricultura land Environmental Implications. Elsevier. Advances in Agronomy. Volume 141, 2017, Pages 1-51.

Laird, D. A., Fleming, P. D., Davis, D. D., Horton, R., Wang, B., Karlen, D. L. 2010. Impact of biochar amendments on the quality of a typical Mid western agricultural soil. Geoderma 158:443-449

Novizan. 2004 . Petunjuk Pemupukan Yang Ekfektif. Agro Media Utama.Jakarta

Opat. Yudith, 2017. Pengaruh Takaran Biochar Dan Kompos Kirinyuh Terhadap Pertumbuhan dan Hasil Tanaman Selada Darat

Schuchardt ,U., Sercheli, R, And Vargas, R. M.,1998, Transesterification Of Vegetable Oils: Areview, J, Braz Chem, Soc., 9, 199-210.

Siburian, Prima. 2007. Empat Belas Masalah Kesehatan Utama Pada Lansia. http://www.waspada.co.id/index.php?view=article\&catid=28\%3Ake sehatan\&id=3812\%3Aempat-belas-masalah kesehatan utama-pada lansia \& forma $\mathrm{t}=$ pdf\&option=com_content diakses pada tanggal 13 februari 2014

Subani S.2016. Pengaruh Jenis Biochar dan Teh Kompos terhadap Pertumbuhan dan Hasil Tanaman Selada Darat (Lactuca sativa, L). Skripsi. Program Studi Agroteknologi, Fakultas Pertanian, Universitas Timor.

Suwastika, A. A. N. G. dan Sutari, N. W. S. 2009.Perlakuan aktivator dan masa inkubasi terhadap pelapukan limbah jerami padi. Jurnal Bumi Lestari IX: 211-216.

Yuniwati, M., F Iskarima, Dan A. Padulemba. 2012 Optimasi Kondisi Proses Pembuatan Kompos Dari Sampah Organik dengan Cara Fermentasi 